\title{
PEMBELAJARAN BIOLOGI MENGGUNAKAN PROBLEM SOLVING DI SERTAI DIAGRAM TREE UNTUK MEMBERDAYAKAN KEMAMPUAN BERPIKIR LOGIS DAN KEMAMPUAN MENAFSIRKAN SISWA
}

\author{
Ahmad Walid ${ }^{1}$, Erik Perdana Putra ${ }^{2}$, Asiyah ${ }^{3}$ \\ 1,2. Department of Science Education, IAIN Bengkulu. Raden Fatah Street, Pagar Dewa, Bengkulu 38211, \\ Indonesia \\ Coressponding Author. E-mail: \\ 1 ahmadwalid@iainbengkulu.ac.id \\ 2 erikperdana1988@gmail.com
}

Online Published: 13 Januari 2019

\begin{abstract}
Abstrak
Problem solving adalah metode belajar di mana siswa dilatih memiliki kemampuan merumuskan permasalahan yang kompleks dan membuat sejumlah solusi untuk kemudian merefleksikan solusi tersebut dari berbagai sudut pandang. Sintak dari Problem Solving adalah (1) pendidikan dan peserta didik menyusun permasalahan sebagai bahan belajar, (2) pendidik menjelaskan kegiatan yang akan dilakukan oleh peserta didik, (3) peserta didik baik secara individu/kelompok mendapat sebuah bahan pemecahan masalah yang sama, (4) pada ahir kegiatan belajar pendidik/peserta ditunjuk menyimpulkan dan (5) pendidik dan peserta didik melakukan evaluasi proses dan hasil. Jurnal yang mendukung berjudul Penerapan Metode Pembelajaran Problem Solving Model Polya Untuk Meningkatkan Kemampuan Memecahkan Masalah. Tree Diagram(diagram pohon) adalah sebuah tipe diagram secara spesifik yang memiliki topologi network (hubungan) yang unik. (1) masalah utama dijabarkan ke dalam masalah yang lebih kecil, (2) masalah yang sudah dijabarkan itu kemudian dijabarkan lagi ke masalah yang lebih kecil, (3) mengadakan identifikasi jaringan hubungan komponen-komponen yang ada. Dukungan peneliti berjudul Aplikasi Network Pohon Dalam Tree Diagram. Pokok bahasan materi karena keanekaragaman hayati merupakan prinsip klasifikasi dan siswa dapat menafsirkan dan merupakan kompetensi yang terkait dengan KPS. Keanekaragaman hayati mempunyai nilai rendah 49,72. Melalui Problem Solving dan Diagram Pohon diharapkan dapat mendorong kemampuan berfikir logis dan kemampuan menafsirkan. Kesimpulan dari Problem Solving dan Diagram Pohon diharapkan dapat diterapkan dalam pembelajaran terutama pada materi keanekaragaman hayati untuk dapat meningkatkan kemampuan berfikir logis dan kemampuan menafsirkan. Saran perlu dilaksanakan penelitian tentang penggunaan model Problem Solving dan tehnik Diagram Pohon untuk memberdayakan berfikir logis dan menafsirkan.
\end{abstract}

Kata Kunci: Problem Solving dan Diagram Pohon, Kemampuan Berfikir Logis, Kemampuan menafsirkan.

\section{BIOLOGICAL LEARNING USING PROBLEM SOLVING IN THE TREE DIAGRAM TO EMPOWER LOGICAL THINKING AND ABILITY TO INTERPRETATE STUDENTS}

\begin{abstract}
Problem solving is a learning method in which students are trained to have the ability to form complex problems and make a number of solutions to then reflect on these solutions from various perspectives. The syntax of Problem Solving is (1) education and students develop problems as learning material, (2) educators explain the activities to be carried out by students, (3) students either individually / in groups receive a problem solving material, (4) at the end of the learning activity the educator / participant is appointed to conclude and (5) the educator and the students evaluate the process and results. Supporting journals entitled Application of Learning Methods Problem Solving Polya Model to Improve Problem Solving Ability. Tree Diagram (tree diagram) is a specific type of diagram that has a unique network topology (relationship). (1) the main problem is translated into a smaller problem, (2) the problem that has been described is then elaborated into a smaller problem, (3) establishing a network identification of the relationships of existing components. The support of the researcher is titled the Tree Network Application in the Tree Diagram. Material subject matter because biodiversity is a principle of classification and students can
\end{abstract}


interpret and constitute competencies related to PPP. Biodiversity has a low value of 49.72. Through Problem Solving and Tree Diagrams it is expected to encourage logical thinking skills and interpreting skills. The conclusions of Problem Solving and Tree Diagrams are expected to be applied in learning especially in biodiversity material to be able to improve logical thinking skills and interpreting abilities. Suggestions need to be carried out research on the use of Problem Solving models and Tree Diagram techniques to empower logical thinking and interpreting.

Keywords: Problem Solving and Tree Diagram, Logical Thinking Skill, Interpreting Skill 


\section{PENDAHULUAN}

Pendidikan adalah salah satu sarana untuk meningkatkan kualitas sumber daya manusia. Peningkatan kualitas sumber daya manusia merupakan prasyarat mutlak untuk mencapai tujuan pendidikan. Undang Undang Sistem Pendidikan Nasional No. 20 tahun 2003, menyatakan bahwa tujuan pendidikan nasional adalah mencerdaskan kehidupan bangsa dan mengembangkan manusia Indonesia seutuhnya yaitu manusia yang bertakwa terhadap Tuhan Yang Maha Esa dan berbudi pekerti luhur, memiliki pengetahuan dan keterampilan, kesehatan jasmani dan rohani, kepribadian yang mantap dan mandiri serta tanggung jawab kemasyarakatan dan kebangsaan (UUSPN, 2007:5). Seiring dengan tujuan pembentukan siswa yang berkualitas tersebut, Sekolah Menengah Atas (SMA) adalah salah satu lembaga sekolah yang mempunyai fungsi dan tanggung jawab untuk membawa jalannya proses pendidikan yang baik dan bermutu.

Belum banyak siswa memiliki pemikiran yang logis terhadap pembelajaran biologi. Peranan guru masih saja dominan dan guru masih kurang membuat siswa untuk berfikir logis. Siswa masih cenderung berfikir bahwa Ilmu Pengetahuan Alam adalah pelajaran hafalan.

Pemikiran yang kritis dan logis dalam tulisan dapat dilihat dari cara seseorang menyampaikan ide serta gagasannya dalam bentuk kalimat efektif. Kalimat yang logis (masuk akal) dapat dipahami dengan mudah, cepat, dan tepat serta tidak menimbulkan salah paham. Oleh karena itu, kemampuan berpikir logis sangat penting dalam menulis argumentasi, agar apa yang dismpaikan penulis mudah dimengerti oleh pembaca. Jadi, supaya seseorang dapat menulis karangan argumentasi terlebih dahulu harus mempu berpikir secara (Gusnita Roza Putri, dkk, 2012)

Untuk memberdayakan berfikir logis dan kemampuan menafsirkan siswa dapat dilatihkan melalui model, salah satu model pembelajaran adalah Problem Solving disertai Diagram Tree. Menurut Setyawan, 2008 Problem solving adalah suatu cara penyajikan pelajaran dengan mendorong peserta didik untuk mencari atau memecahkan suatu masalah atau persoalan dalam rangka pencapaian tujuan pengajaran.

Metode problem solving merupakan sebuah metode yang berorintasi pada proses belajar mengajar. Shepherd (2000) mengemukakan bahwa problem solving adalah metode belajar di mana siswa dilatih memiliki kemampuan merumuskan permasalahan yang kompleks dan membuat sejumlah solusi untuk kemudian merefleksikan solusi tersebut dari berbagai sudut pandang.

Diagram Pohon atau Tree adalah teknik yang dapat digunakan dalam pembelajaran biologi untuk memecahkan konsep apa saja, seperti kebijakan, target, tujuan, sasaran, gagasan, persoalan, tugas-tugas, atau aktivitas-aktivitas secara lebih rinci ke dalam sub-subkomponen, atau tingkat yang lebih rendah dan rinci.

\section{KAJIAN TEORI}

Model Problem Solving (pemecahan masalah) adalah salah satu model mengajar yang mengandung aktivitas belajar siswa cukup tinggi dan termasuk model yang disarankan dalam GBPP 1994. Pendekatan model ini termasuk kepada pendekatan interaksi sosial yang menitik beratkan kepada aktivitas memecahkan masalah baik individu maupun kelompok (Tin Rustini, 2008).

Menurut Kokom Komariah (2011) Problem Solving dapat diartikan sebagai rangkaian aktivitas pembelajaran yang menekankan kepada proses penyelesaian masalah yang dihadapi secara ilmiah. Terdapat 3 ciri utama dari problem solving

1. Problem solving merupakan rangkaian aktivitas pembelajaran, artinya dalam implementasi Problem Solving ada sejumlah kegiatan yang harus dilakukan siswa. Problem Solving tidak mengharapkan siswa hanya sekedar mendengarkan, mencatat, kemudian menghafal materi pelajaran, akan tetapi melalui problem solving siswa aktif berpikir, berkomunikasi, mencari dan mengolah data, dan akhirnya menyimpulkan.

2. Aktivitas pembelajaran diarahkan untuk menyelesaikan masalah. problem solving menempatkan masalah sebagai kata kunci dari proses pembelajaran. Artinya, tanpa masalah maka tidak mungkin ada proses pembelajaran.

3. Pemecahan masalah dilakukan dengan menggunakan pendekatan berpikir secara ilmiah. Berpikir dengan menggunakan metode ilmiah adalah proses berpikir 
deduktif dan induktif. Proses berpikir ini dilakukan secara secara sistematis dan empiris. Sistematis artinya berpikir ilmiah dilakukan melalui tahapan-tahapan tertentu; sedangkan empiris artinya proses penyelesaian masalah didasarkan pada data dan fakta yang jelas.

Salah satu model pemecahan masalah adalah model Polya dalam Kokom Komariah (2011). Langkah-langkah dalam pembelajaran problem solving menurut Polya ada 4, yaitu : (1) memahami masalah, (2) menentukan rencana strategi penyelesaian masalah, (3) menyelesaikan strategi penyelesaian masalah, dan (4) memeriksa kembali jawaban yang diperoleh. Pembelajaran ini dimulai dengan pemberian masalah, kemudian siswa berlatih memahami, menyusun strategi dan melaksanakan strategi sampai dengan menarik kesimpulan. Guru membimbing siswa pada setiap langkah problem solving dengan memberikan pertanyaan yang mengarah pada konsep.

Kelebihan pembelajaran problem solving menurut Haryanti (2010) adalah sebagai berikut:

(1) Mendidik siswa untuk berpikir sistematis

(2) Mampu mencari jalan keluar terhadap situasi yang dihadapi

(3) Belajar menganalisis suatu masalah dari berbagai aspek

(4) Mendidik siswa percaya diri sendiri

(5) Berpikir dan bertindak kreaktif

(6) Memecahkan masalah yang dihadapi secara realistis

(7) Dapat membuat pendidikan sekolah lebih relevan dengan kehidupan, khususnya dunia kerja

(8) Merangsang perkembangan kemajuan berpikir siswa untuk menyelesaikan masalah yang dihadapi dengan tepat.

Kelemahan pembelajaran problem solving

(1) Memerlukan waktu yang cukup banyak

(2) Kemampuan siswa dalam memecahkan masalah berbeda beda ada yang sempurna dalam memecahkan masalah tetapi ada juga yang kurang dalam memecahkan masalah.

Menurut Adhi Darmawan Sutjiadi (2009) Tree Diagram(diagram pohon) adalah sebuah tipe diagram secara spesifik yang memiliki topologi network (hubungan) yang unik. Dapat disebut juga diagram dalam bentuk network dimana setiap kemungkinan yang ada saling dihubungkan satu sama lain untuk menemukan suatu kemungkinan secara detail. Tree Diagram juga dianggap sebagai network diagram yang secara spesifik bergantung pada hubungan antar situasi, yang juga dapat dilihat sebagai suatu jenis khusus dalam cluster diagram.

Sebagai suatu alat atau teknik dalam mengidentifikasi dan menganalisis masalah, analisis pohon masalah mempunyai banyak kegunaan. Alat analisis ini membantu untuk mengilustrasikan korelasi antara masalah, penyebab masalah, dan akibat dari masalah dalam suatu hirarki faktorfaktor yang berhubungan. Analisis ini digunakan untuk menghubungkan berbagai isu atau faktor yang

berkontribusi pada masalah organisasi dan $m$ embantu untuk mengidentifikasi akar penyebab dari masalah organisasi tersebut.

Duffy, dkk. (2012) menyatakan tree diagram merupakan suatu alat generik yang dapat diadaptasikan untuk berbagai maksud yang luas diantaranya:

1. Mengembangkan langkah-langkah logis untuk mencapai hasil yang spesifik.

2. Melakukan analisis five whys dalam mengeksplorasi penyebab.

3. Mengkomunikasikan untuk mendorong keterlibatan dalam pengembangan hasil yang didukung bersama.

4. Menggali pada level yang lebih rinci suatu alur proses.

5. Menggambarkan secara grafik suatu perkembangan hirarkis, seperti silsilah atau skema klasifikasi.

d

Langkah-langkah dalam diagram pohon adalah sebagai berikut :

(1) masalah utama dijabarkan ke dalam masalah yang lebih kecil, (2) masalah yang sudah dijabarkan itu kemudian dijabarkan lagi ke masalah yang lebih kecil, (3) mengadakan identifikasi jaringan hubungan komponen-komponen yang ada.

Penjelasan di atas model Problem Solving digabungkan dengan diagram pohon karena Problem Solving dapat mendidik siswa mampu berfikir sistematis, mampu mencari jalan keluar terhadap situasi yang dihadapi, sedangkan diagram 
pohon mengembangkan langkah-langkah logis untuk mencapai hasil yang spesifik, jadi model Problem Solving dapat digabungkan dengan diagram pohon.

\section{PEMBAHASAN}

Hasil di atas menunjukkan bahwa melalui model Problem Solving disertai diagram pohon diharapkan dapat mendorong kemampuan berfikir logis siswa dan kemampuan menafsirkan siswa.

Hasil berupa gambar, atau data yang dibuat gambar/skema/grafik/diagram/sebangsa-nya, pemaparannya juga mengikuti aturan yang ada; judul atau nama gambar ditaruh di bawah gambar, dari kiri, dan diberi jarak 1 spasi dari gambar. Bila lebih dari 1 baris, antarbaris diberi spasi tunggal. Sebagai contoh, dapat dilihat pada Gambar 1.

Pembahasan difokuskan pada mengaitkan data dan hasil analisisnya dengan permasalahan atau tujuan penelitian dan konteks teoretis yang lebih luas. Dapat juga pembahasan merupakan jawaban pertanyaan mengapa ditemukan fakta seperti pada data.

Pembahasan ditulis melekat dengan data yang dibahas. Pembahasan diusahakan tidak terpisah dengan data yang dibahas.

\section{SIMPULAN DAN SARAN}

Berdasarkan hasil di atas model Problem Solving diharapkan dapat diterapkan dalam pembelajaran, terutama pada materi keanekaragaman hayati untuk dapat meningkatkan kemampuan berfikir logis siswa dan kemampuan menafsirkan siswa.

Saran yang dapat dilakukan untuk kedepannya adalah Perlu dilaksanakan penelitian tentang penggunaan model Problem Solving dan tehnik Diagram Pohon untuk memberdayakan berfikir logis dan menafsirkan.

\section{DAFTAR PUSTAKA}

Duffy, Gace L., Scott A. Laman, Pradip Mehta, Goving Ramu, Natalia Scriabina, dan Keith Wagoner. 2012. Beyond The Basics: Seven New Quality Tools Help Innovate, Communicate, and Plan. Http:/www. Asqqm.org/resourcesmodule/download_re source/id/881/.

Guri-Rozenblit，S. (1989). Effects of a Tree Diagram on Students' Comprehension of Main Ideas in an Expository Text with Multiple Themes. Reading Research Quarterly, 24(2), 236-247. doi:10.2307/747866

Komariah Kokom. 2011. Penerapan Metode Pembelajaran Problem Solving Model Polya Untuk Meningkatkan Kemampuan Memecahkan Masalah Bagi Siswa Kelas IX J Di SMPN 3 Cimahi. Universitas Negeri Yogyakarta

Putri Roza Gusnita dan kawan-kawan. 2012. Hubungan Kemampuan Kemampuan Berpikir Logis Dengan Kemampuan Menulis Karangan Argumentasi Siswa Kelas X SMA NEGERI 1 RAO Kabupaten Pasman. Universitas Negeri Padang

Rustini Tin. 2008. Penerapan Model Problem Solving untuk Meningkatkan Pengembangan Potensi Berpikir Siswa Dalam Pembelajaran IPS di Sekolah Dasar.

Shepherd, G. (2000). The Probe Method: A Through Investigate Approach to Learning. [Online].Tersedia.

http://www.unca.edu/edtech/probe2.htm. (3 April 2010)

Sutjiadi Darmawan Adhi. 2009. Aplikasi Network Pohon Dalam Tree Diagram. Institut Teknologi Bandung. 
